\title{
Possibility of Using Biogrout for Stabilization of Sand Dunes in Desert Areas with Approach in Conservation of Archaeological Remains
}

\author{
Alireza Baghbanan ${ }^{* 1}$, Farshad Ramezanifar ${ }^{2}$, Hamid Hashemolhosseini ${ }^{3}$, Mehdi Razani ${ }^{4}$ \\ ${ }^{1}$ Associate Professor, Department of Mining Engineering, Isfahan University of Technology, IRAN \\ ${ }^{2}$ M.A. Rock Mechanics, Department of Mining Engineering, Isfahan University of Technology, IRAN \\ ${ }^{3}$ Associate Professor, Department of Civil Engineering, Isfahan University of Technology, IRAN \\ ${ }^{4} \mathrm{PhD}$ candidate, Faculty of Conservation-Restoration, Art University of Isfahan, IRAN
}

\begin{abstract}
Archaeological sites in desert areas are at risk for destroying and reburied with sand dunes by sand storms. One of the most important issues for archaeologist and conservators in these regions is maintenance of archaeological remains, during the excavation process and after it. There are several sand dune stabilization methods such as mechanical dune stabilization, mulch or protective screen, aerodynamic method and biological fixation (woody and grassy species, planting). However they are mostly expensive and time consuming and may have some harmful effects on environment. In this regard, the bio-grouting technique which produce calcite cements are new approaches to consolidate land in geotechnical engineering. This method has created a potential for archaeological conservation, stabilization procedure for sand dunes or soil. This method works according to the chemical reactions of natural non-pathogenic microorganisms that exist in the soil. The main objective of this research work is to evaluate the possibility of using biological stabilization with calcite-forming bacteria, for consolidating of sand dunes in desert areas with an approach in the conservation of archaeological remains, and archaeological conservation during and after the excavations. In this case sand grains/soil particles are coagulated and make a more dense soil with higher mechanical properties than natural condition. Biological stabilization of sand dunes and soil has been conducted with Sporosarcina Pasteurii Bacteria. When this bacteria supplies with suitable substrates, micro-organisms can catalyze chemical reactions in the subsurface resulting in precipitation of inorganic minerals. These bacteria could microbially catalyze hydrolysis of urea and calcium carbonate reaction when it is cultivated with enough nutritions under proper environmental conditions at laboratory and then it is located on the soil surface with other reactive substances. It results a scaffolding calcite between soil/sand particles. The best reactive environment is achieved at $\mathrm{pH}$ 7-9, temperature of $25{ }^{\circ} \mathrm{C}$ to examine the depth of penetration of biogrout, a cylindrical mold (PVC) tube (by 1 meter high) is filled with dry sand and consolidates with bio-grouts. The results show that the measured depth of bio-consolidation is $50 \mathrm{~cm}$ in dry sand. Soil density is $1.6 \mathrm{gr} / \mathrm{cm} 3$; the permeability of soil is smaller than the normal condition. To control the functional rate and also surface resistance of biogrouted sand, the standard penetration test with $250 \mathrm{~g}$ plummet in the dry and wet conditions have been examined. The results of this test show that bio-consolidation was successfully conducted and depth of plummet penetration becomes negligible.
\end{abstract}

Keywords: Biogrout, Conservation, Archaeological Remains, Biological Stabilization, Running Sands.

*Corresponding author: bagh110@cc.iut.ac.ir 


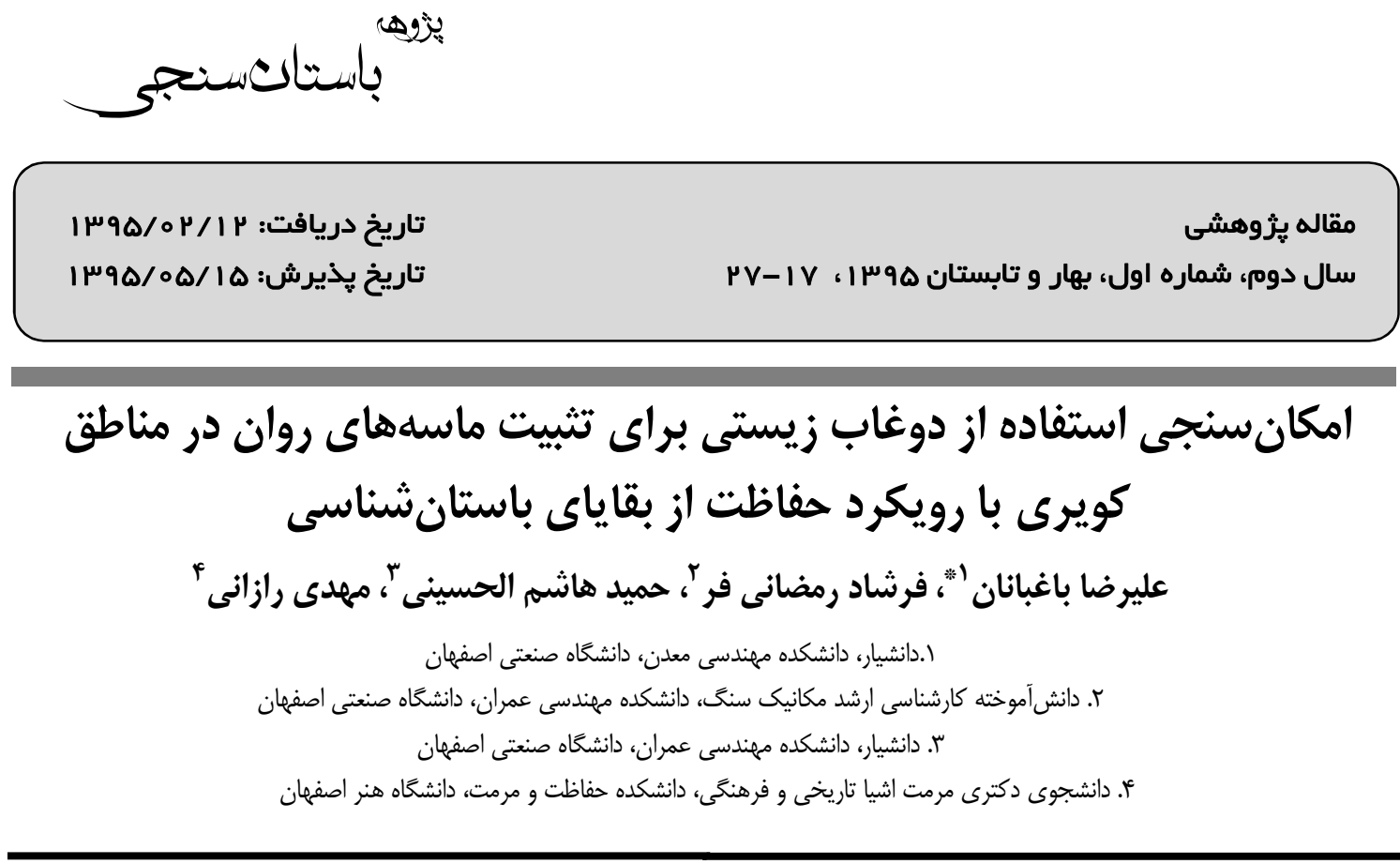

جكيده

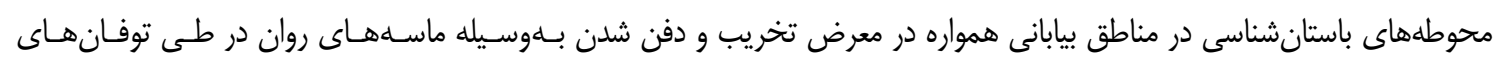

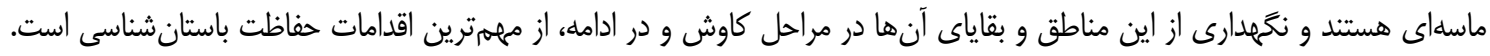

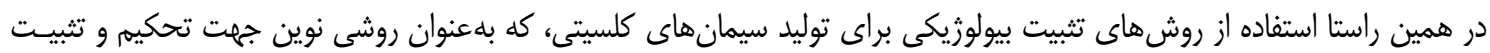

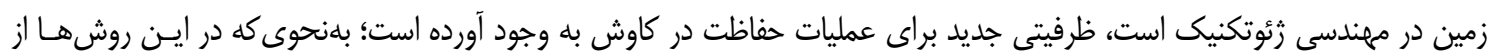

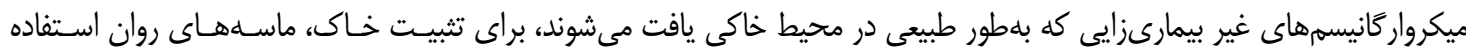

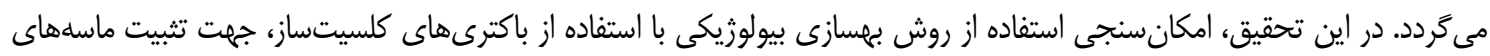

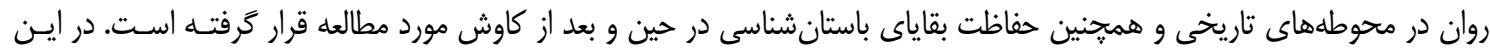

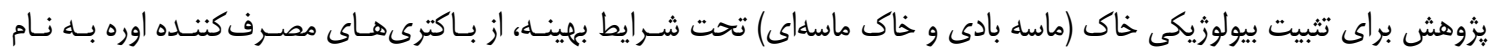
Sporosarcina Pasteurii

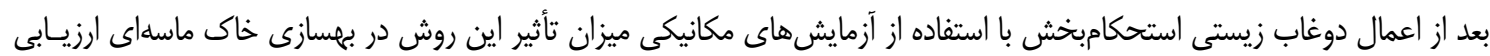

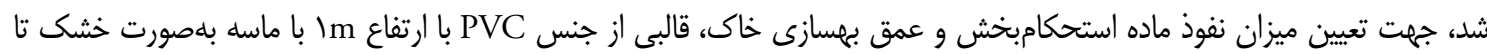

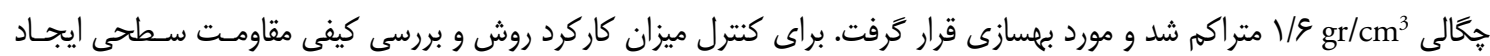

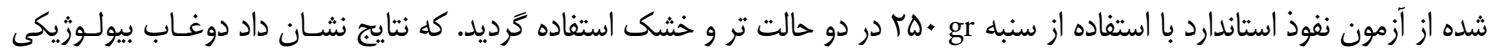

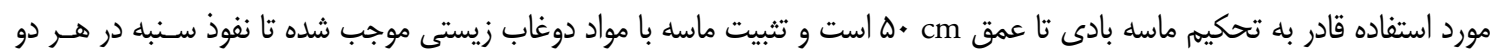

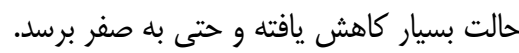

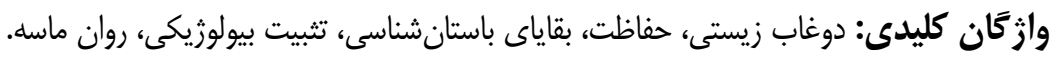

\footnotetext{
" "نويسنده مسئول: مكاتبات: اصفهان، دانشكاه صنعتى اصفهان، دانشكده مهندسى معلن، تلفن :

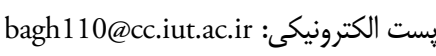

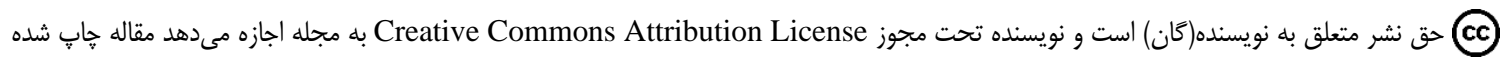
را با ديكران به اشتراك بكذارد منوط بر اينكه حقوق مؤلف اثر حفظ و بهان انتشار اوليه مقاله در اين مجله اشاره شود. 
همجنين به هيج وجه نمىتوان از مالج بهعنوان يك مـاده

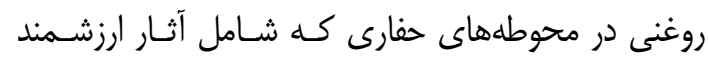

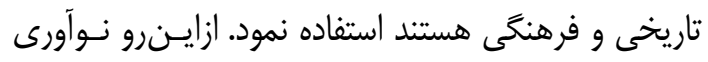

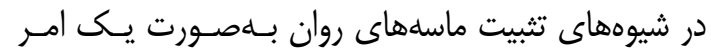

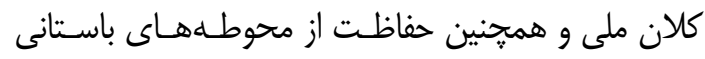

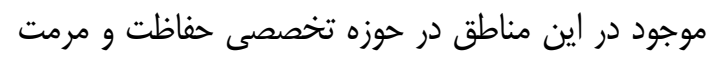

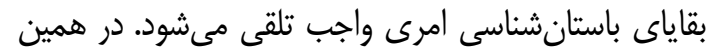

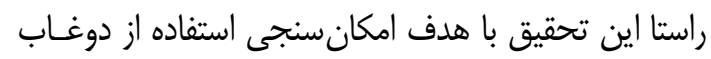

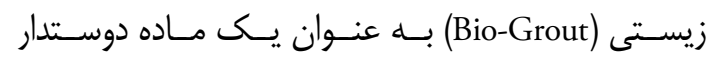

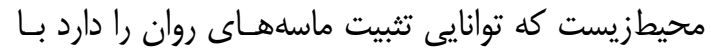
رويكرد حفاظـت از محوطـهــاى باسـتانشناسـى انجـام

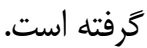

\section{r- بيشينه تحقيق}

حفاظت و مرمت ابنيه تاريخى و بقاياى برجا در محوطـهـ-

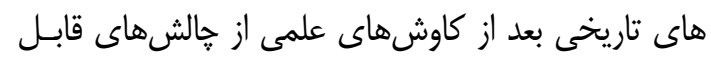

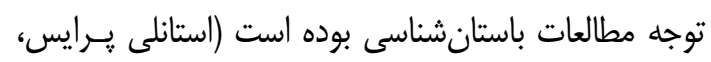

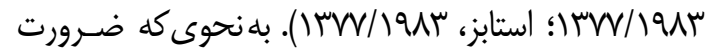

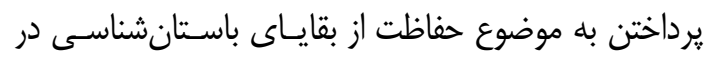

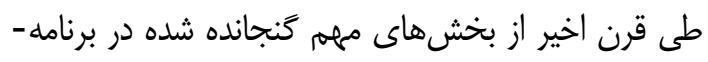

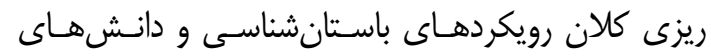

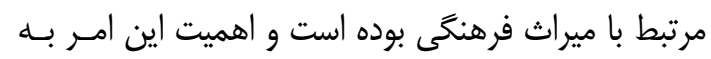

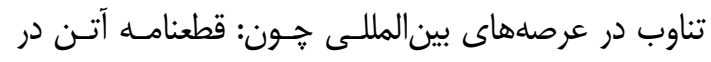

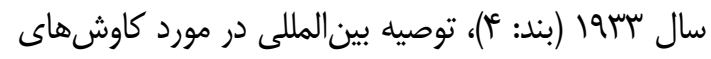

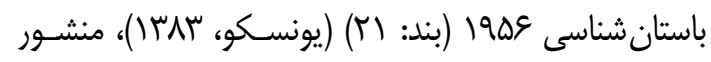

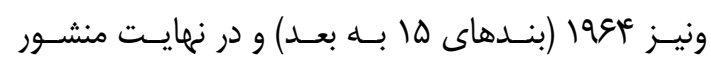

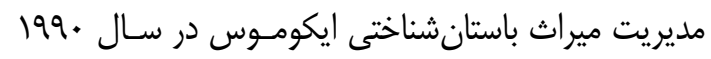

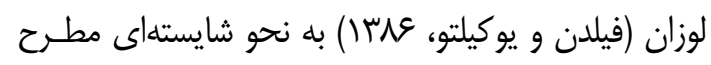

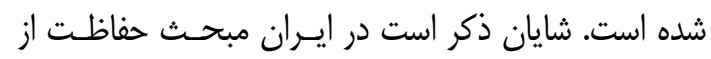

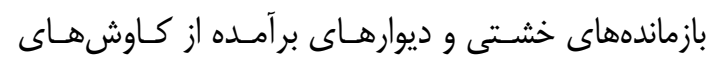

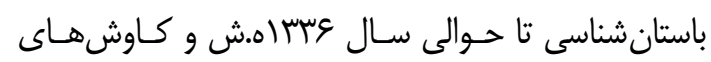

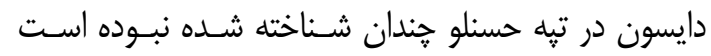

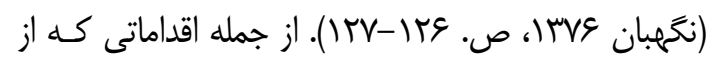

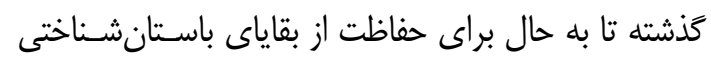

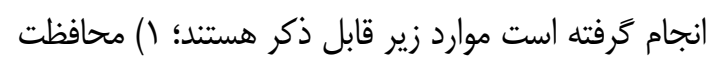

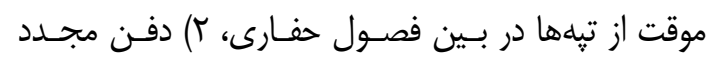
(Reburial)

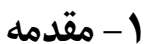

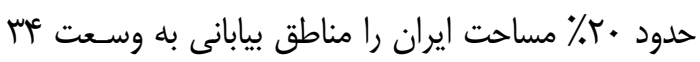

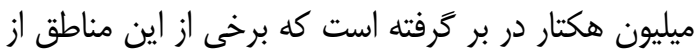

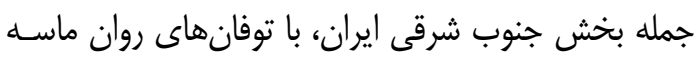

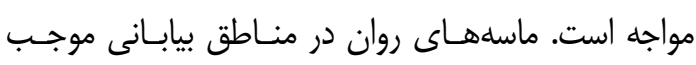

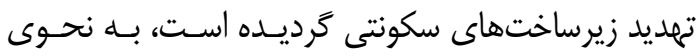

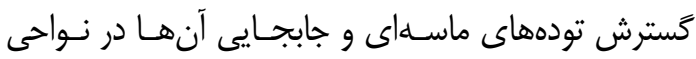

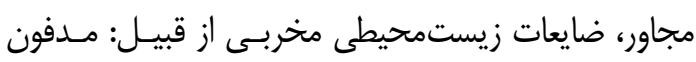

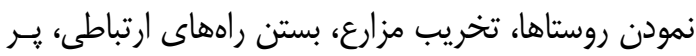

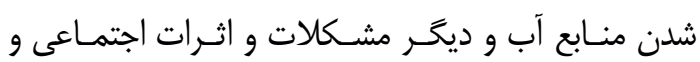

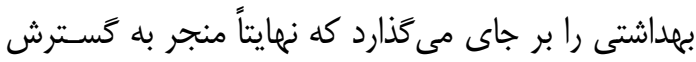

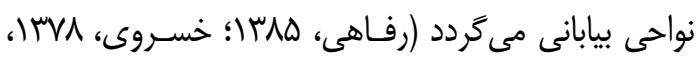

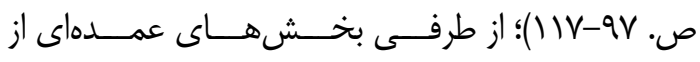

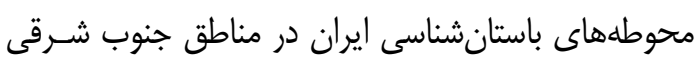
و مركزى در نواحى بيابانى و نيمه بيابانى قرار دارند، كه از ازئ داطي

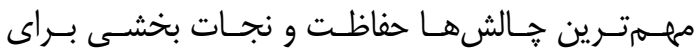

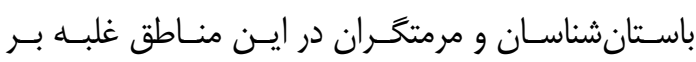

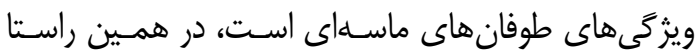

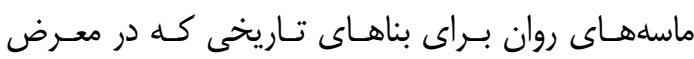

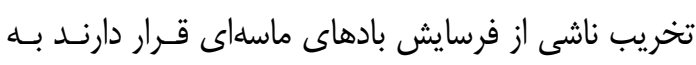

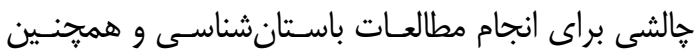

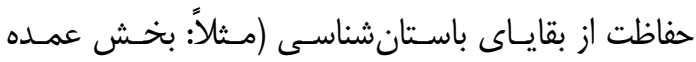
محوطههاى باستانى دهانه غلامان و محوطههاى اقمارى بانى

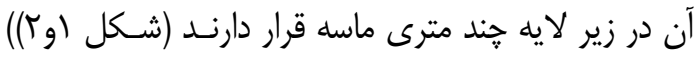
تبديل شده است.

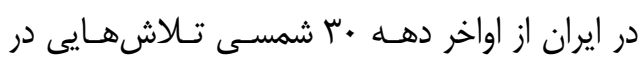

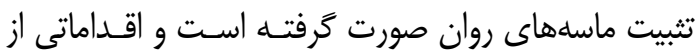

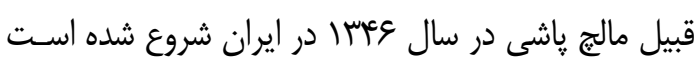

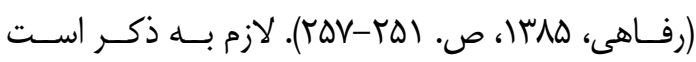

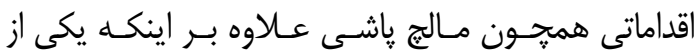

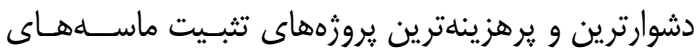
روان است همواره بلهعنوان عملى موقت مطرح بودين برده است. زيرا كه پِ از طـى مـدت زمـانى خـاص مـالج توانـايى جسبندگى خود را از دست داده و عـلاوه بـر تكـرار مـوارد

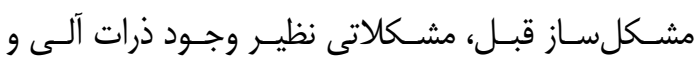
خطرناك همراه با جريان ماسـهــاى روان را در يـى دارد. 


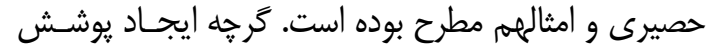
كياهى در راستاى اهداف زيستمحيطى اسـت امـا زمـان

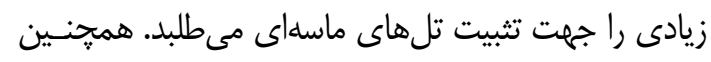

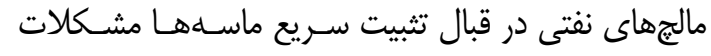

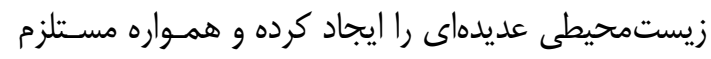
تكرار ايـن عمليـات هسـتند (رفـاهى، هـشا). اسـتفاده از روش هاى بيولوزيكى براى بهسازى زمين، ززينهاى جديد

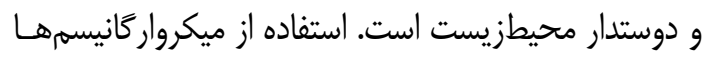

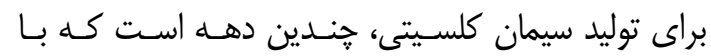

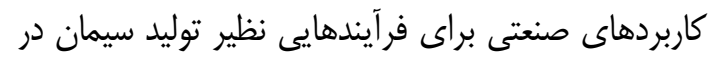

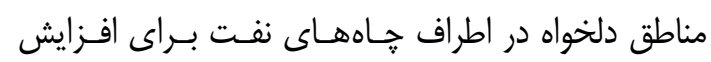
ميزان بازيابى از مخازن نفتى (Ferris et al., 1997)، غيــر

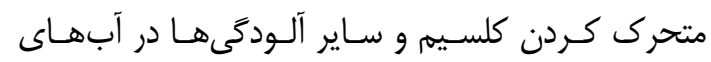

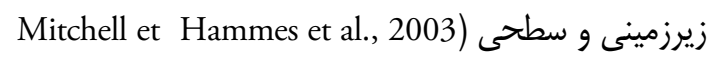
Le () (al., 2005; (Metayer-Levrel, 1999

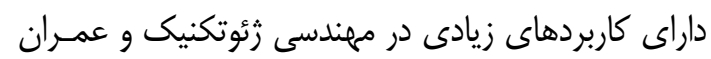

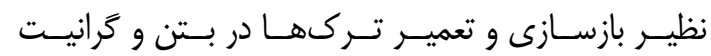
(Ramachandran et al., 2001; Gollapudi et al., 1995)

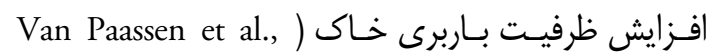

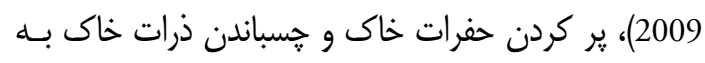

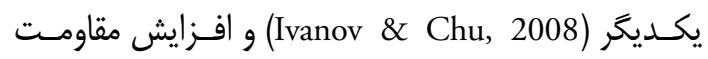
برشى خاى (DeJong et al., 2006) است. در اين روشها

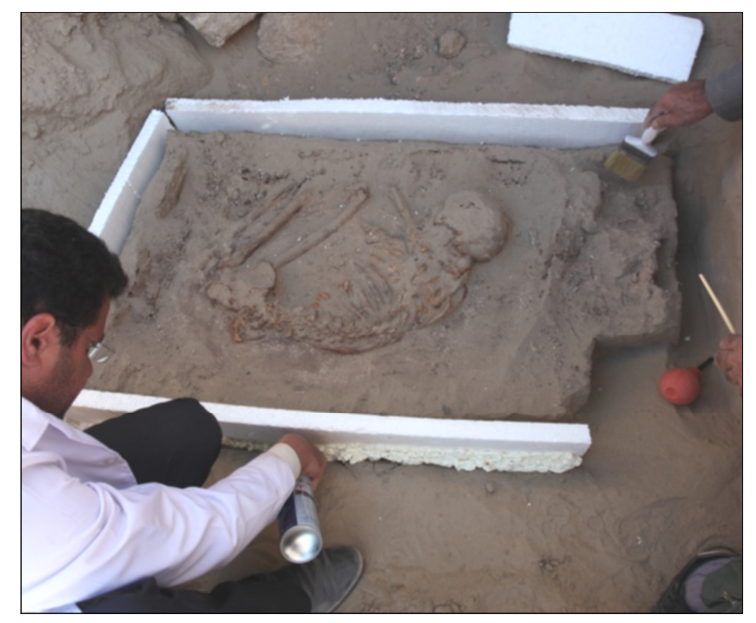

شكل ז: نجات اسكلت باستانى در ميان روان ماسههاى محوطه ميراث جهانى و باستانشناختى شهر سوخته سيستان (مأخذ: سيد

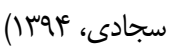

آجر كشى و يوشاندن ديوارها و آثار باقىمانده در محـل، عأ) سقف زنى و جانيناهها روى محوطه براى حفاظت دائمسى

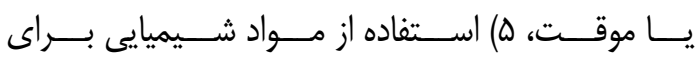

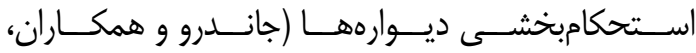

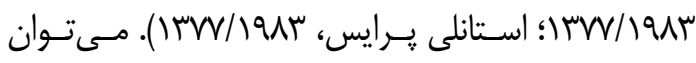

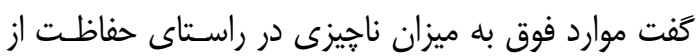

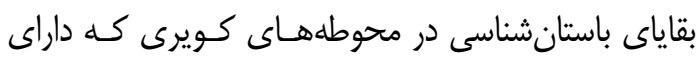
توفانهاى روان ماسه هستند؛ مىتواند كاربرد داشته باشند.

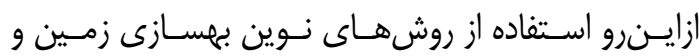

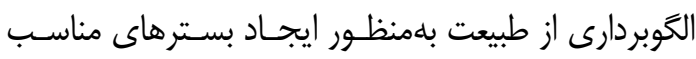
جهت اهداف عمرانى و حفاظتى، علاوه بر مزايـايى نظيـر

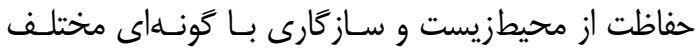

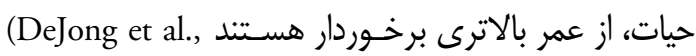

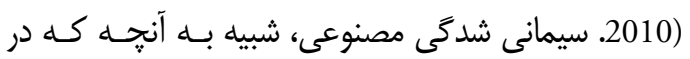

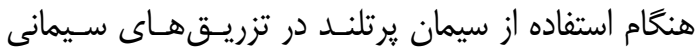

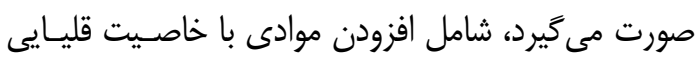

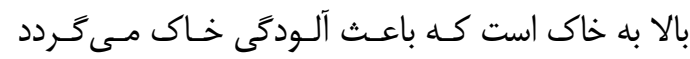
(Ozdogan, 2010). بسيارى از دوغابهاى شـيميايى نيـز

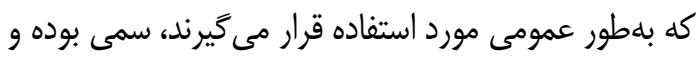

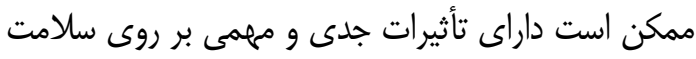
انسان و محيطزيست داشته باشند (Reuben, 2003).

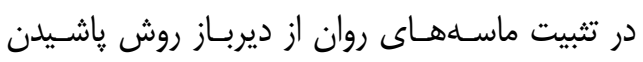

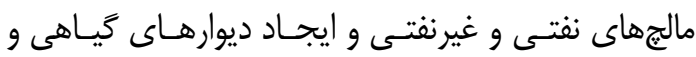

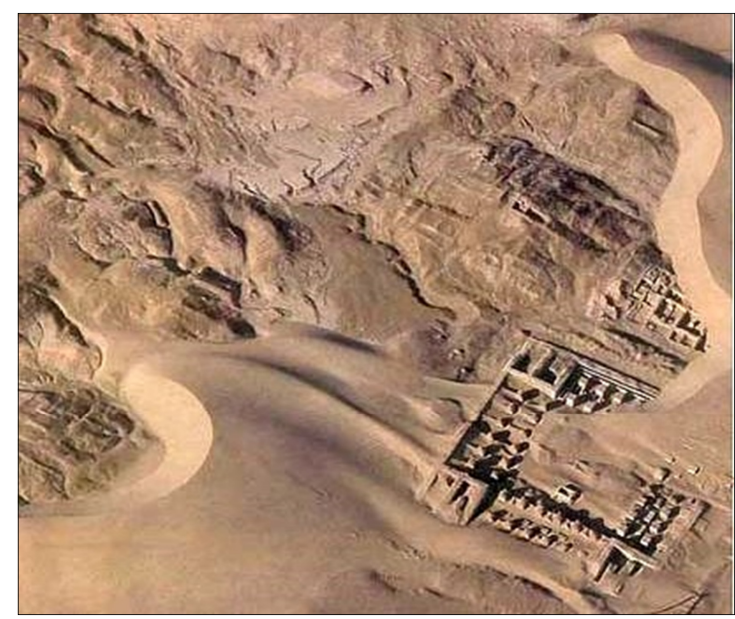

شكل ا: محوطه باستانى دهانه غلامان و محوطههاى كاوش شده آن كه در تيههاى ماسه روان محصور شدهاند (مأخذ: باشكاه خبرنغاران

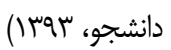



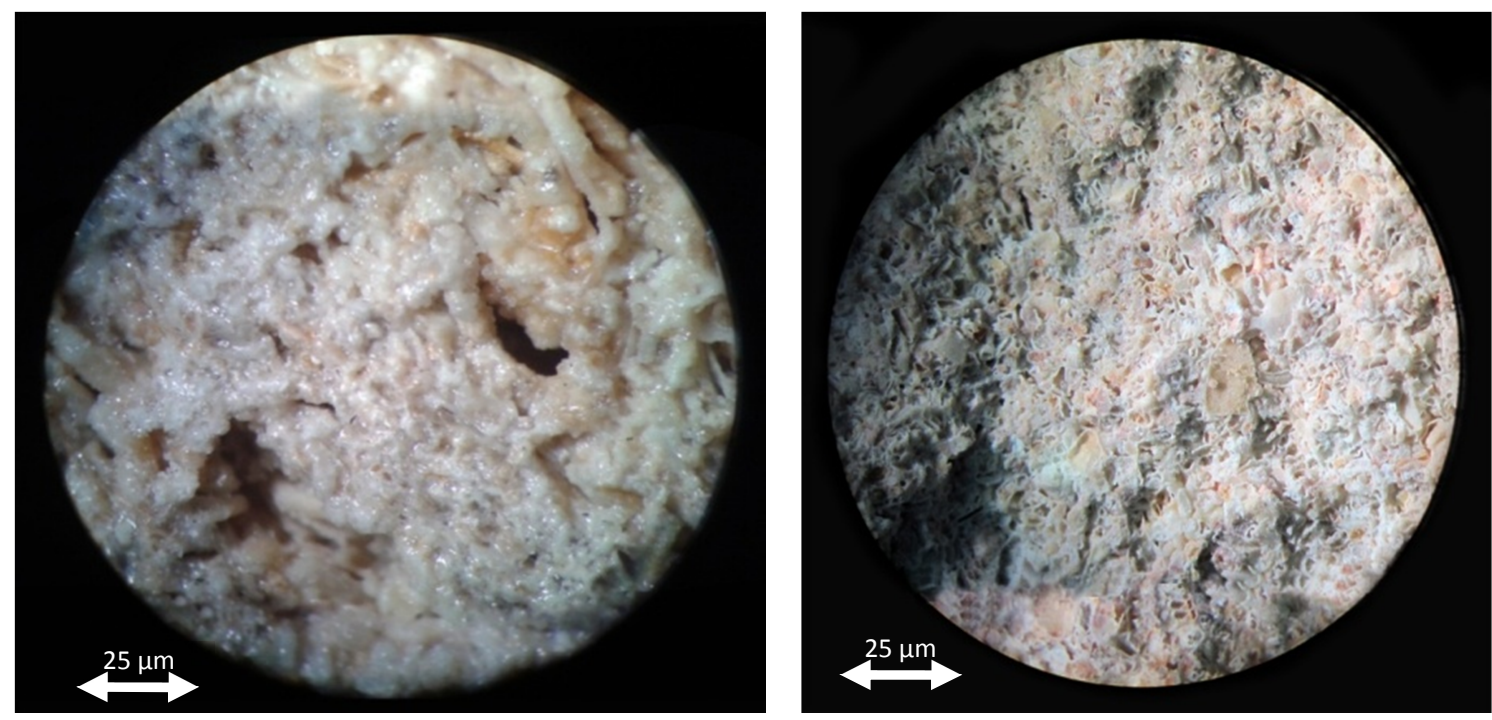

شكل": مقايسه شيوه عملكرد و بهسازى سطح متخلخل با استفاده از ميكروار كانيسم باكتريايى

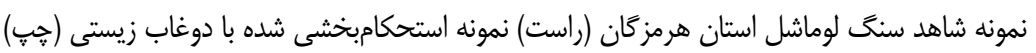

ماسه ريختهَّرى با دانهبندى مشخص نشان داده مىشود

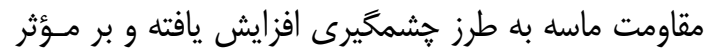

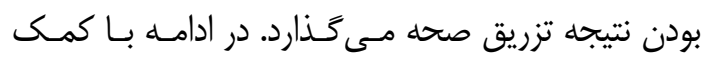

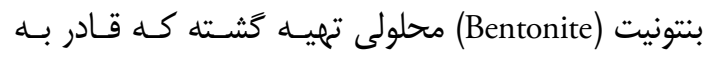

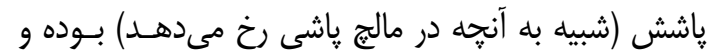

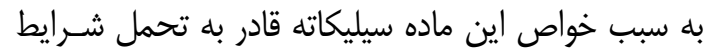

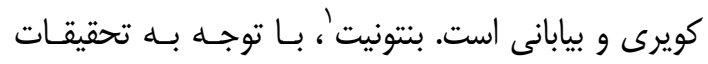

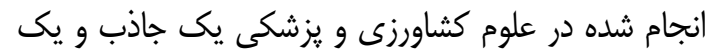
كند كننده تلقى شده و شبيد اسفنج مواد محلول و يونها، را جذب كرده و بعد به كندى رها مىسازد. يس إس از تعيسين

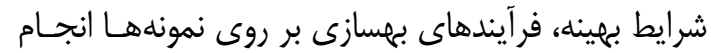

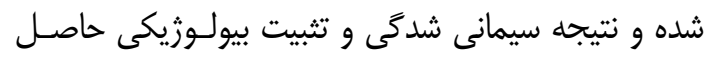

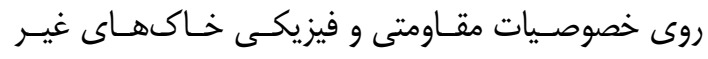

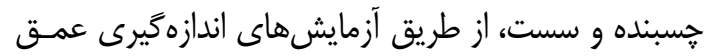

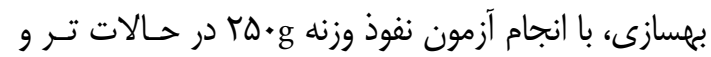

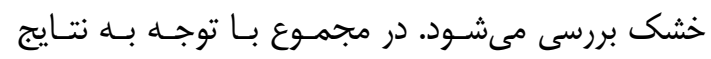

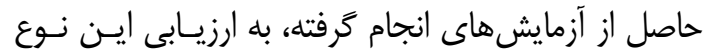

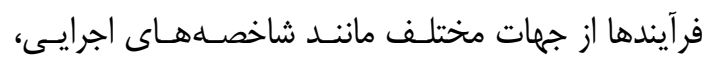
زيستمحيطى و مقاومتى يرداخته شده و امكان استفاده از

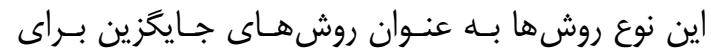

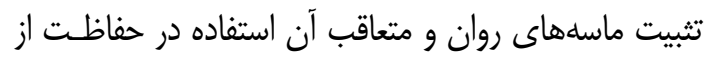
بقاياى باستانشناسى مورد بحث و تحليل قرار مى گيرد.
از ميكروار كانيسمهاى غير بيمارىزايى كه بلهـور طبيعى

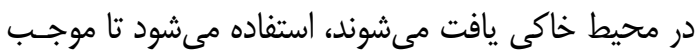
توليد سيمان طبيعى در مواد متخلخل از جمله خاك كر درد.

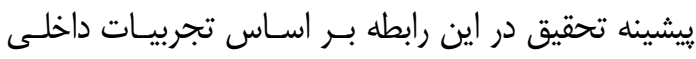

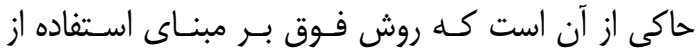

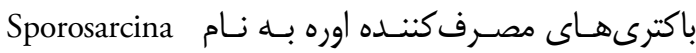

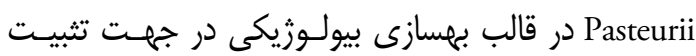
ماسههاى روان و مبارزه با ريزگَردها (رمضانى فـر، بوسا)،

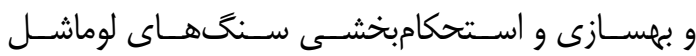

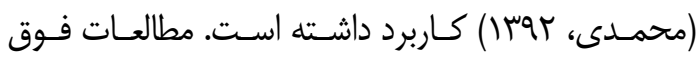

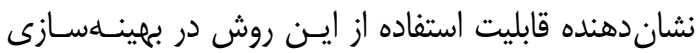
سطوح متخلخل است (شكل r).

\section{س-روش تحقيق}

فرآيند اصلى اين تحقيق، بـر سـيمانى شـدَى كلسـيتى و

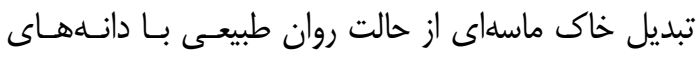

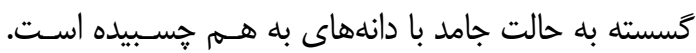

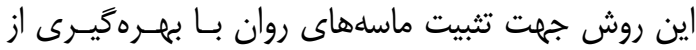

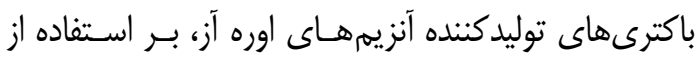

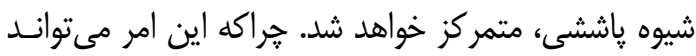
مفيدترين راهكار براى سطوح وسيع قلمداد شود. در همين

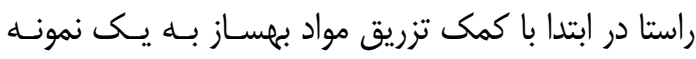

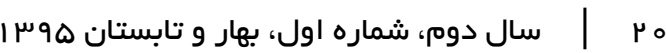


خود، داراى بار منفى هستند، موجـب جـذب سـطح ذرات خاكى مىشوند كه بلهطور نسبى غلظتهاى بالايى از مـواد

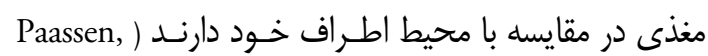
(2009; Jonkers, 2009

$$
\text { آمونياك }
$$

$\mathrm{NH}_{2}-\mathrm{CO}-\mathrm{NH}_{2}+\mathrm{H}_{2} \mathrm{O} \longrightarrow 2 \mathrm{NH}_{3}{ }^{+}+\mathrm{CO}_{2}$

$2 \mathrm{NH}_{3}+2 \mathrm{H}_{2} \mathrm{O} \longrightarrow 2 \mathrm{NH}_{4}^{+}+2 \mathrm{OH}$

$\mathrm{CO}_{2}+\mathrm{OH}^{-} \longrightarrow \mathrm{HCO}_{3}^{-}$

$\mathrm{Ca}^{2+}+\mathrm{HCO}_{3}^{-}+\mathrm{OH}^{-} \longrightarrow \mathrm{H}_{2} \mathrm{O}+\mathrm{CaCO}_{3}$

به دنبال اين فرآيند، باندهايى از سـيمان كلسيتى در فضاهاى خالى موجود بين دانههاى خاك تشكيل مى شوند و باعث جسبيدن ذرات خاك با يكديخر و درنتيجه كاهش مانش

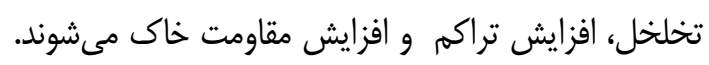
اين امر با ير كردن منافذ و ايجاد زنجيره كلسـيتى همـراه

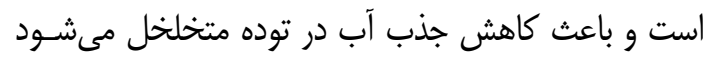

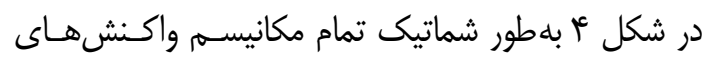
شيميايى كه در ماتريكس ماسه به وقوع مى ييوندند، نشان

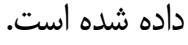

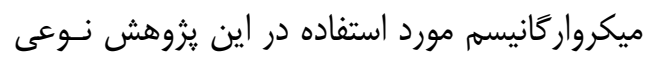
باكترى از خانواده باسيلوسهــا (Bacillaceae family) بـا نام علمى Sporosarcina Pasteurii است. سويه (strain) -

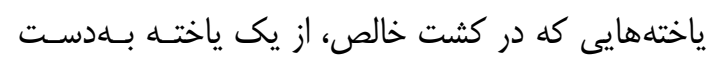

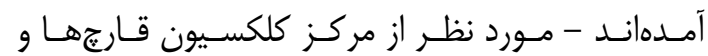

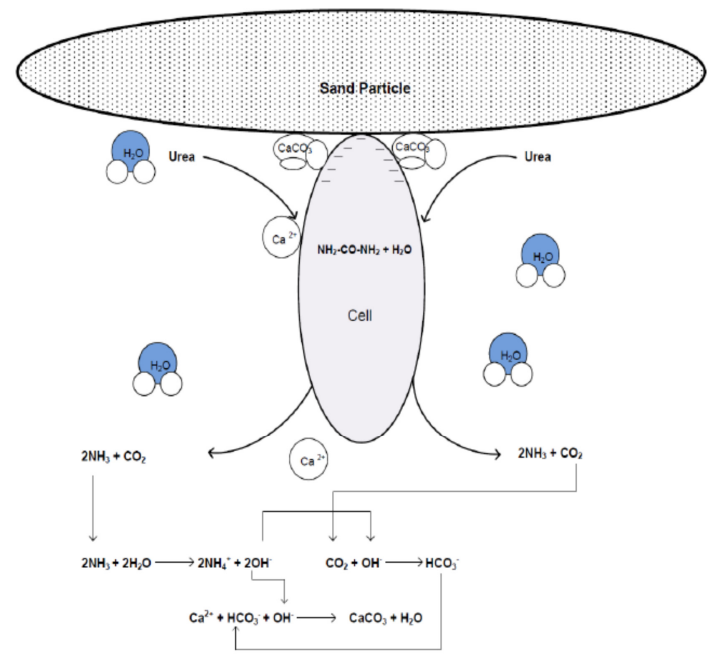

شكل f: شماتيك مكانيسمهاى بيوشيميايى در ماتريكس ماسه (Ozdogan, 2010)

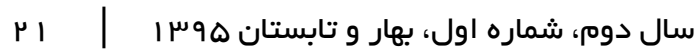

F F مواد و روشهاى مورد استفاده

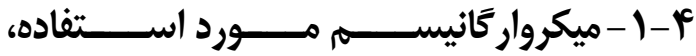

\section{مكانيسمهاى بيوشيميايى و محيط رشد آن}

باكترى Sporosarcina Pasteurii عمومىترين و رايجتـرين

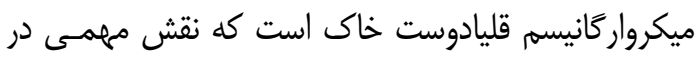

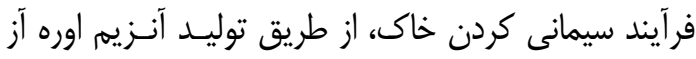

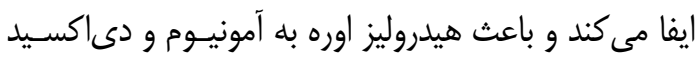

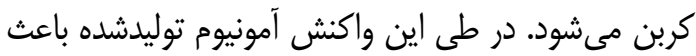

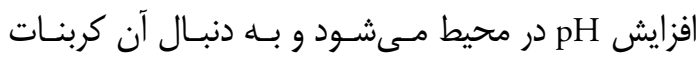

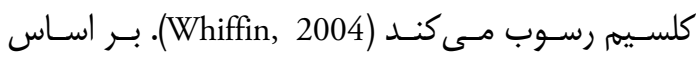

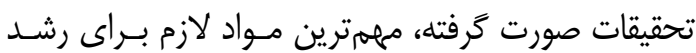

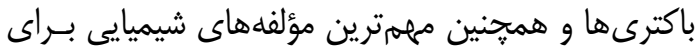

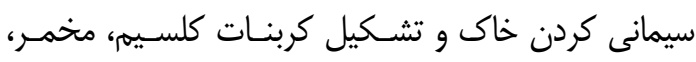

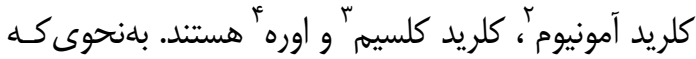
تحت شرايط مطلوب زيستمحيطى، باكترى مـذكور، اوره

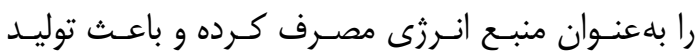

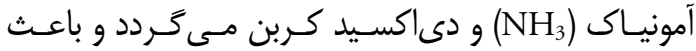

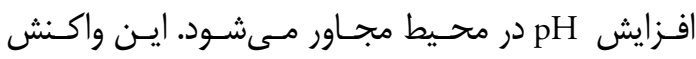

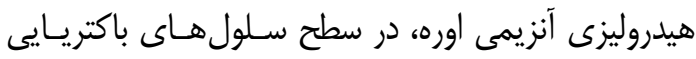

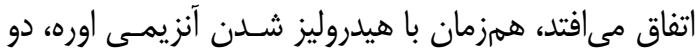

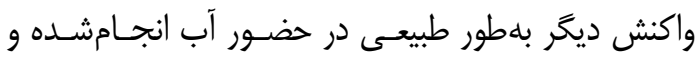
باعث مىشود آمونياك و دى اكسيدكربنى كه بلهوسيله اوره آزاد شدهاند، به يون هاى آمونيـوم (NH

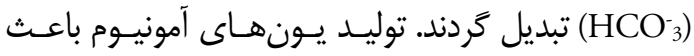

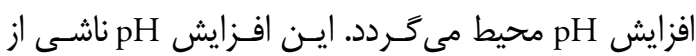

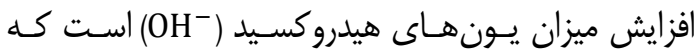
باعث مى شود بهترين و مناسبترين شرايط محيطى براى رشد باكترى ها فراهم آيد تا از اوره موجود تغذيـه كـرده و

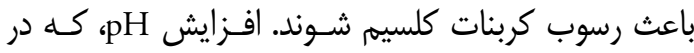

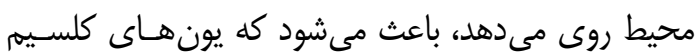

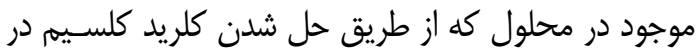

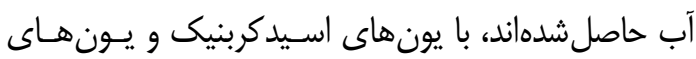

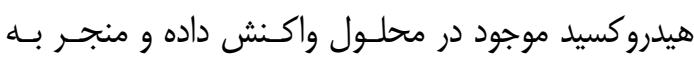

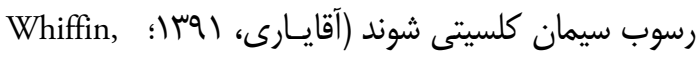

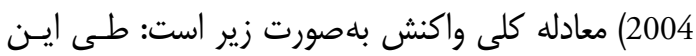

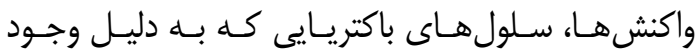
يون هاى هيدرو كسيد ( 
انكوباتور شيكر -مورد استفاده در كشت هوازى باكترىها-

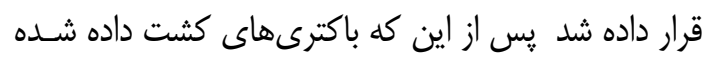

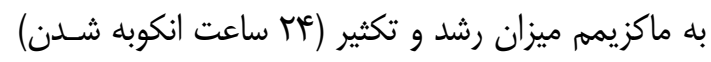
خود رسيد و در انتهاى فاز سكون رشد خود قـرار كرَفتــد،

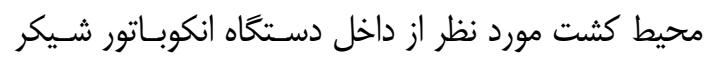

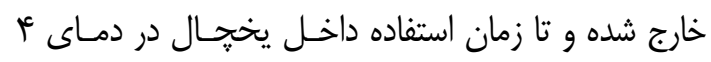
درجه سلسيوس نكَهدارى شد.

r-r-Y - خاك و ماسه بادى مورد استفاده

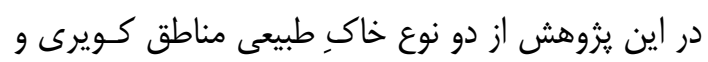

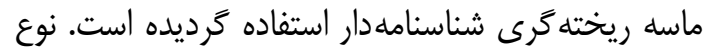

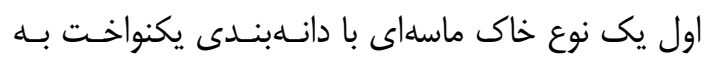

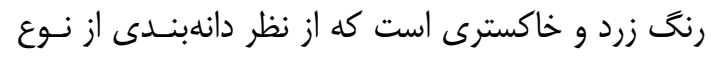

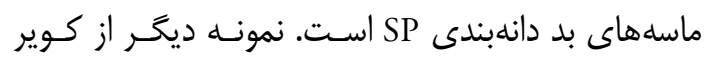

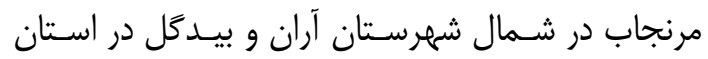

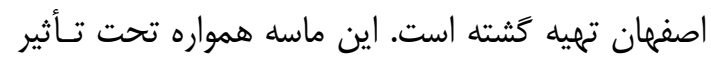

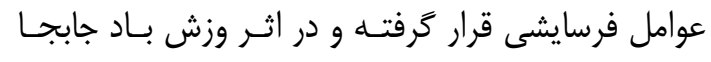
مىشود لذا جهت بهسازى در اين تحقيق مـورد اسـتفاده

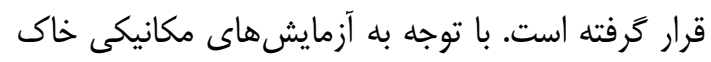

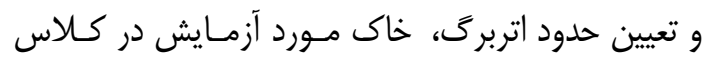
SP-SC

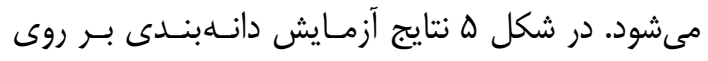

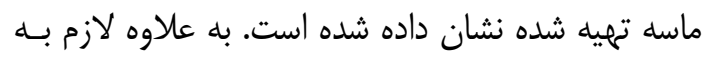

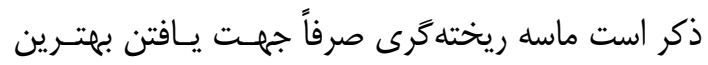

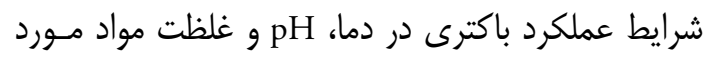
استفاده قرار كرفته است.
جدول (: مواد مورد استفاده و مقادير آنها در محيط كشت مايع

\begin{tabular}{|c|c|}
\hline مقدار & ماده مورد استفاده \\
\hline$r \cdot g$ & عصاره مخمر (Yeast extract) \\
\hline $1 \cdot g$ & كلريد آمونيوم (NH4) \\
\hline $1 \mathrm{~L}$ & آب مقطر \\
\hline
\end{tabular}

PTCC باكترىهاى صنعتى ايران به شـماره شناسـايى

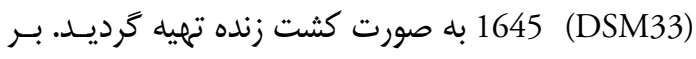

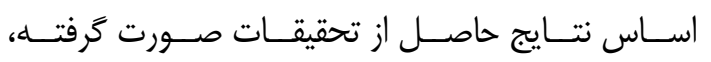
مناسبترين محيط كشت براى ميكروار كانيسم مورد نظـر،

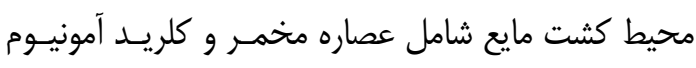

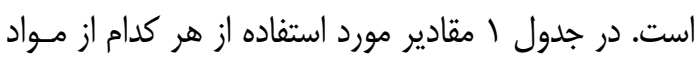
مورد استفاده در محيط كشت آمده است. بر اساس مطالعات ون ياسن (Paassen, 2009) پيس از

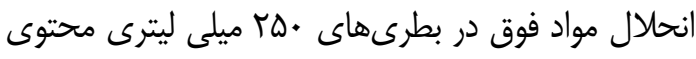

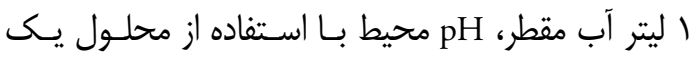

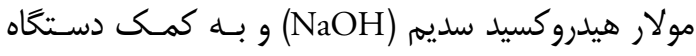

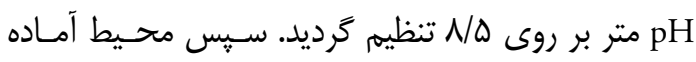

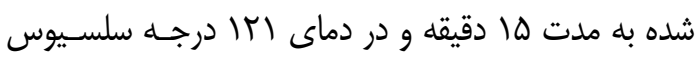

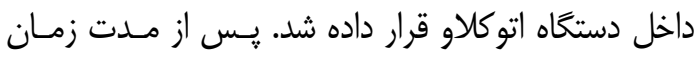

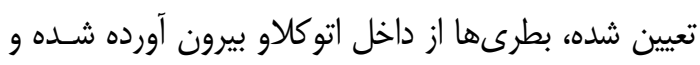

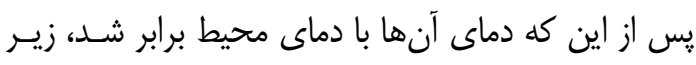

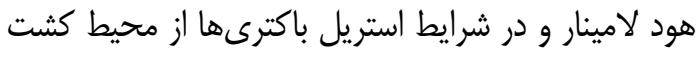

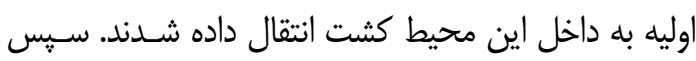

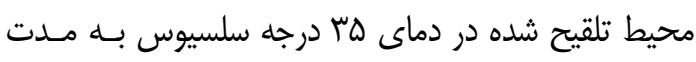

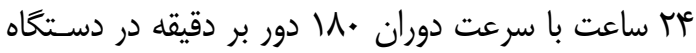

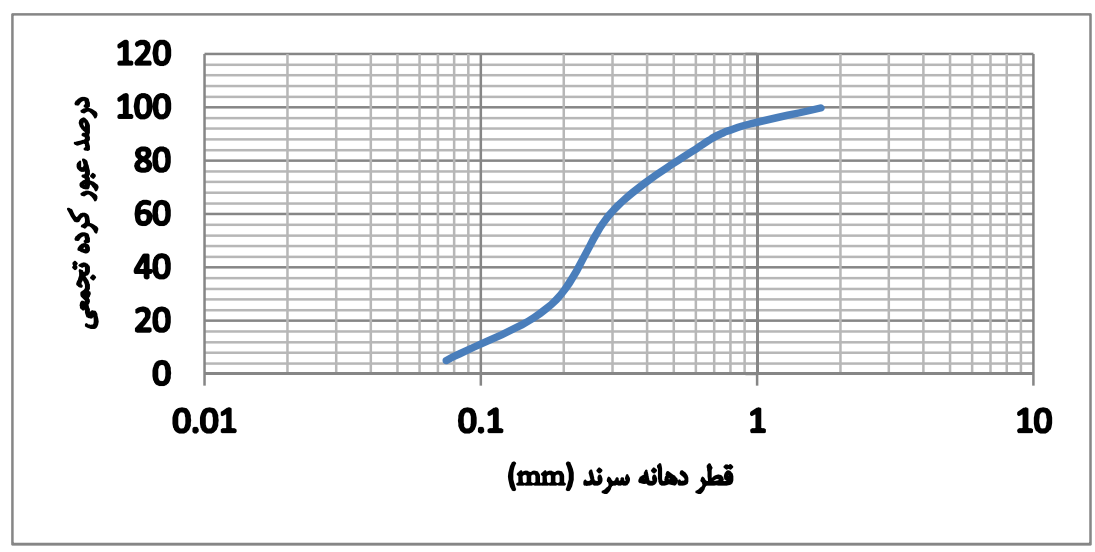

شكل ه: منحنى دانهبندى خاك مورد استفاده 

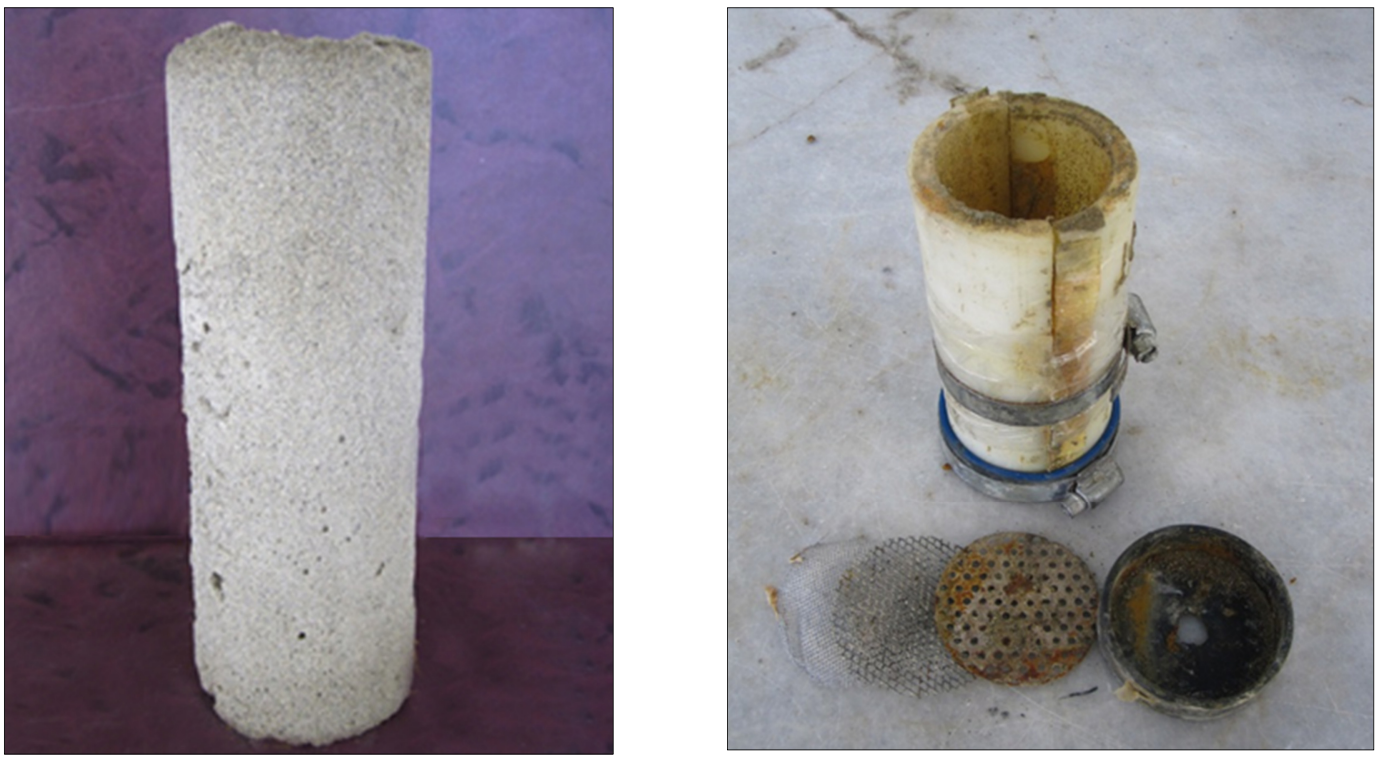

شكل و: قالب استوانهاى PVC و نمونه ماسهاى بهسازى شده آماده جهت آزمايش مقاومت تكمحوره

دوغاب مكيده و به مرور زمان و به كندى رها مى كند. اين

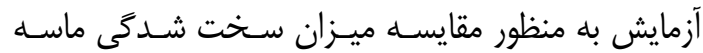

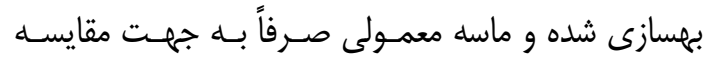
كيفى نمونهها طراحى و ارائه شده است.

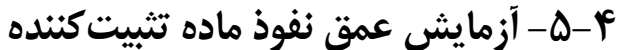
در اين آزمايش به منظور دستيابى به عمق نفـوذ محلـول تثبيت كننده و بهساز و عمق بهسازى ماسه توسط بـاكترى

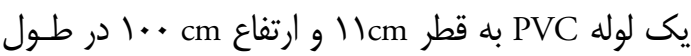
خود شكافته شد سيس درز ايجاد شده با سيليكون گريس

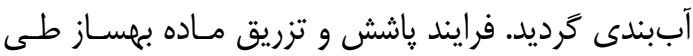
سه مرحله روى نمونه انجام شد به گونهاى كه مواد بهساز

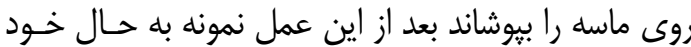

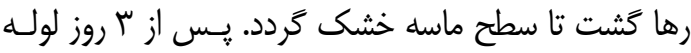

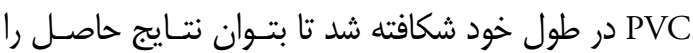

مشاهده نمود.

\section{ه- نتايج و بحث} ه-1 - مقاومت فثارى تكمحوره

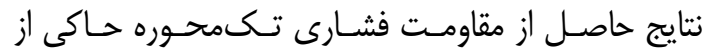
شكست ناگمانى تمام نمونهها بلهصورت شكسـتهـايى در

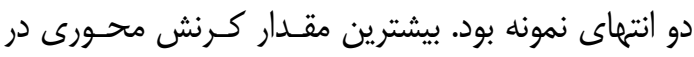

F - Y-آزمايش مقاومت فشارى تك محوره

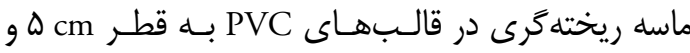
ارتفاع ماس سا تحت تزريق سوسيانسيون باكتريايى قـرار كرفته يس از خشك شدن نمونه هاى تزريق شده و يس

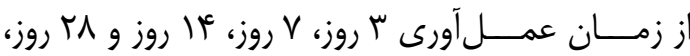
تحت آزمايش مقاومت فشارى تكىمحوى قرار گرفتنـد

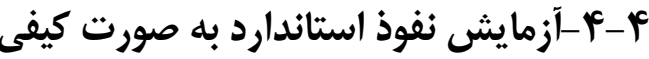

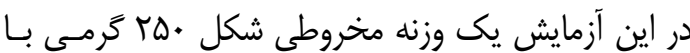

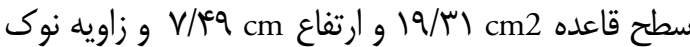

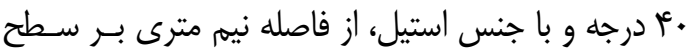

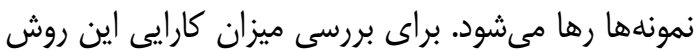

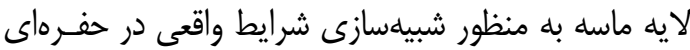

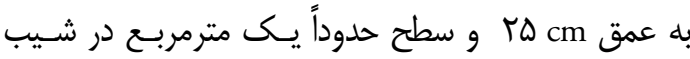
طبيعى در سطح زمين، ريخته شد تا علاوه بر وجود تـابش

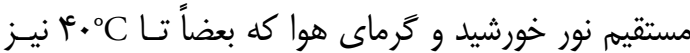

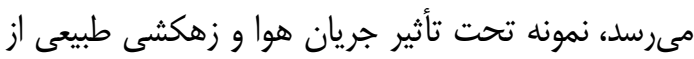

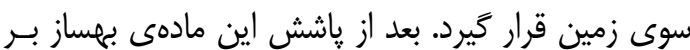

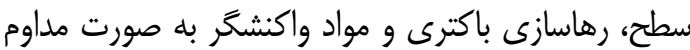

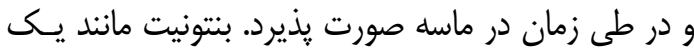

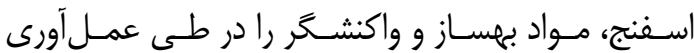




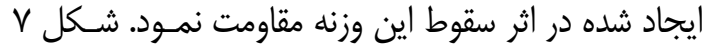

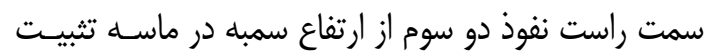

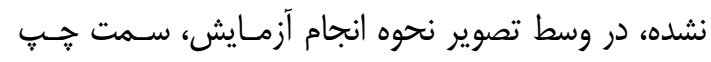

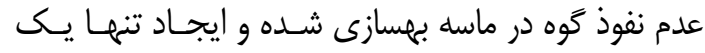
سوراخ در محل اصابت سمبه با ماسه را نشان مىدهد.

\section{ه-" - آزمايش عمق نفوذ ماده تثبيت كننده و} بهساز

نتايج نشان داد باكترى و ماده بهساز توانسته يـك سـتون

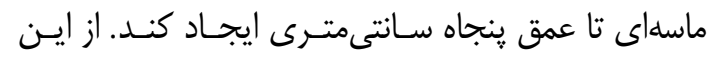

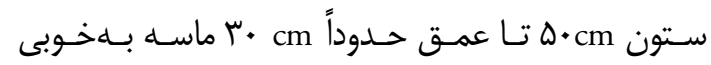

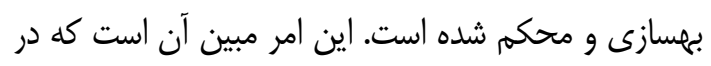

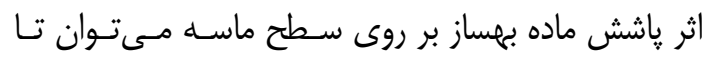

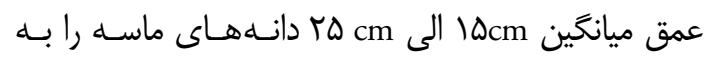

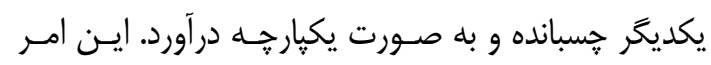
خود كواهى است كه ماسه از حالت روان به حالـت تثبيـت شده تغيير ماهيت داده است (شكل 1).

\section{و-نتيجه كيرى و بيشنهادها}

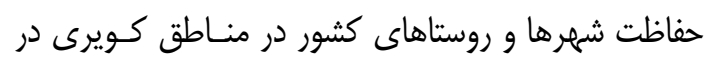

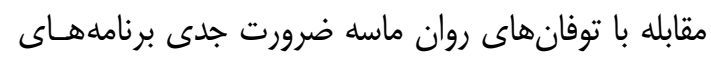
حفاظت از محـيطزيسـت انسـانى اسـت در همــين راسـتا

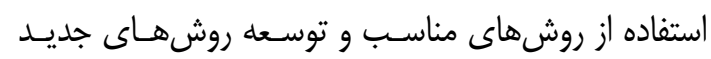

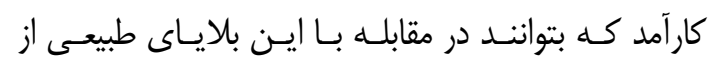

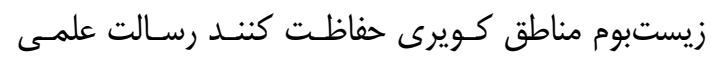

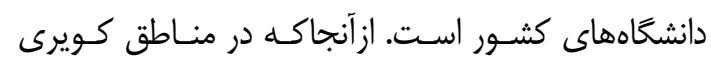

اين آزمايشها r\% بوده كه نشان دهنده ارتبـاط مقاومـــ

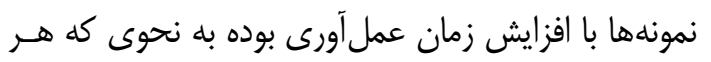

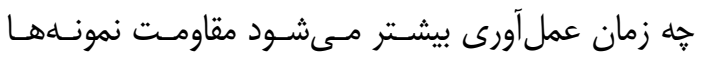

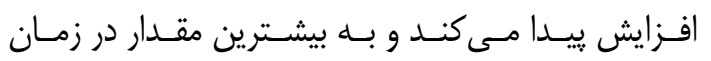

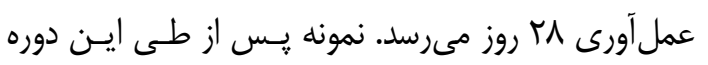

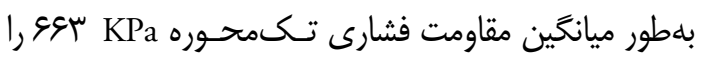
نشان مىدهد كه اين مقدار نسبت به ماسه بهسازى نشاره كه هيج مقاومتى ندارد بسيار خشمخير است.

\section{ه-r-آزمايث نفوذ استاندارد به صورت كيفى}

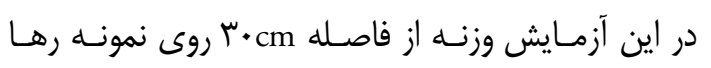

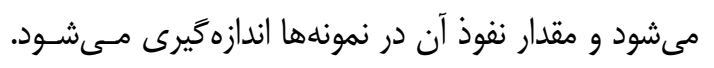

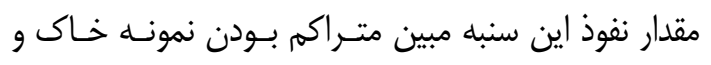

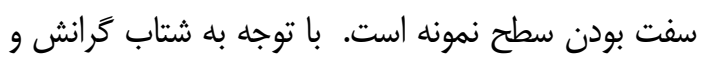
ارتفاع رهاسـازى و وزن ســنبه ميـزان انـرزى وارده برابـر

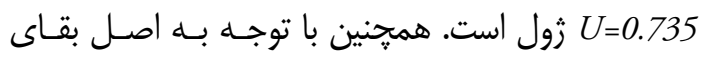

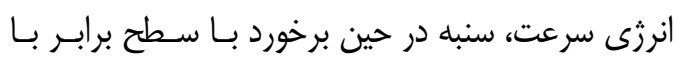

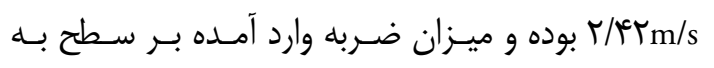

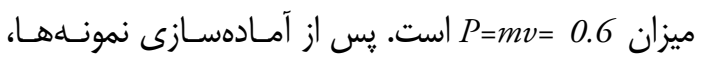

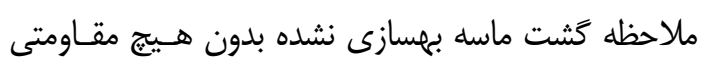

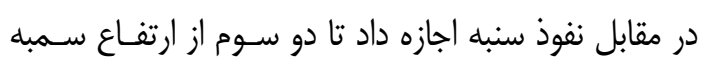

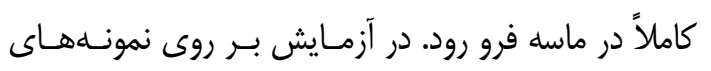

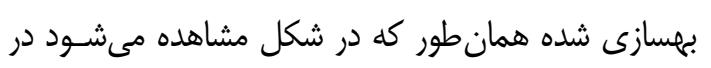

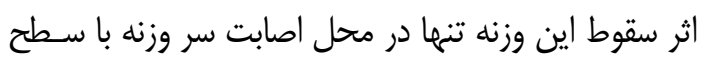

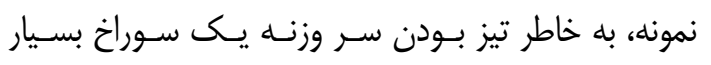

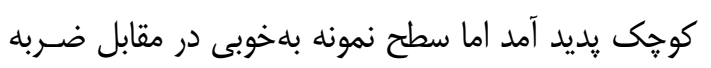
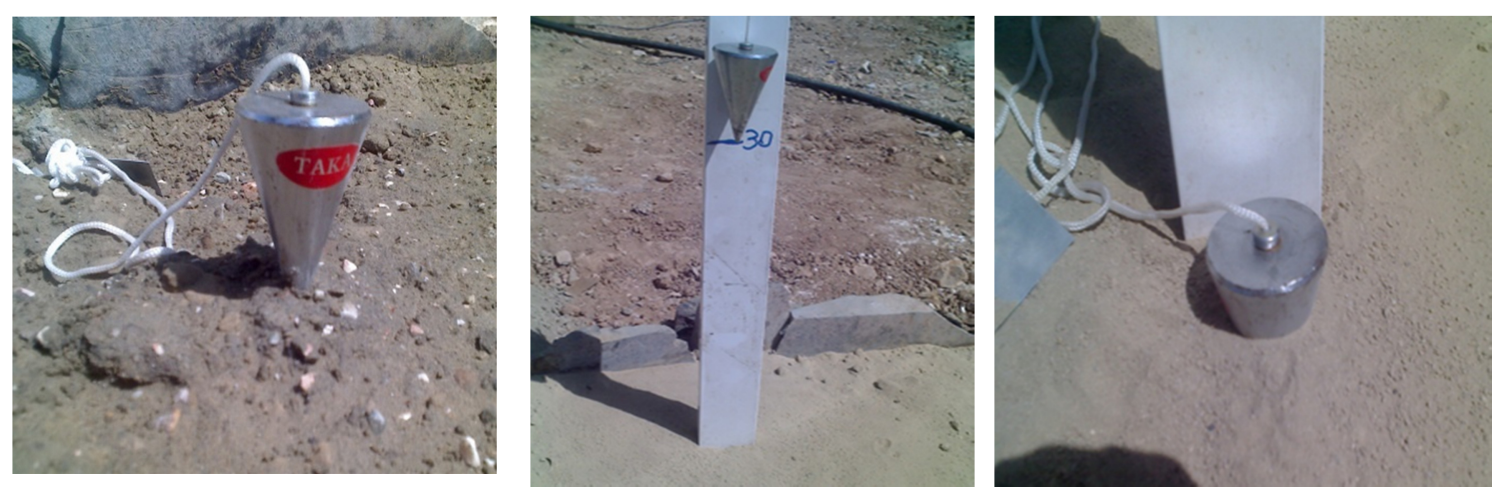

شكل V: به ترتيب از راست: نفوذ سمبه در ماسه تثبيت نشده، رهاسازى سمبه از فاصله cm •"ا، ناتوانى گوه در نفوذ به ماسه تثبيت شده با بايوتكنولوزى 

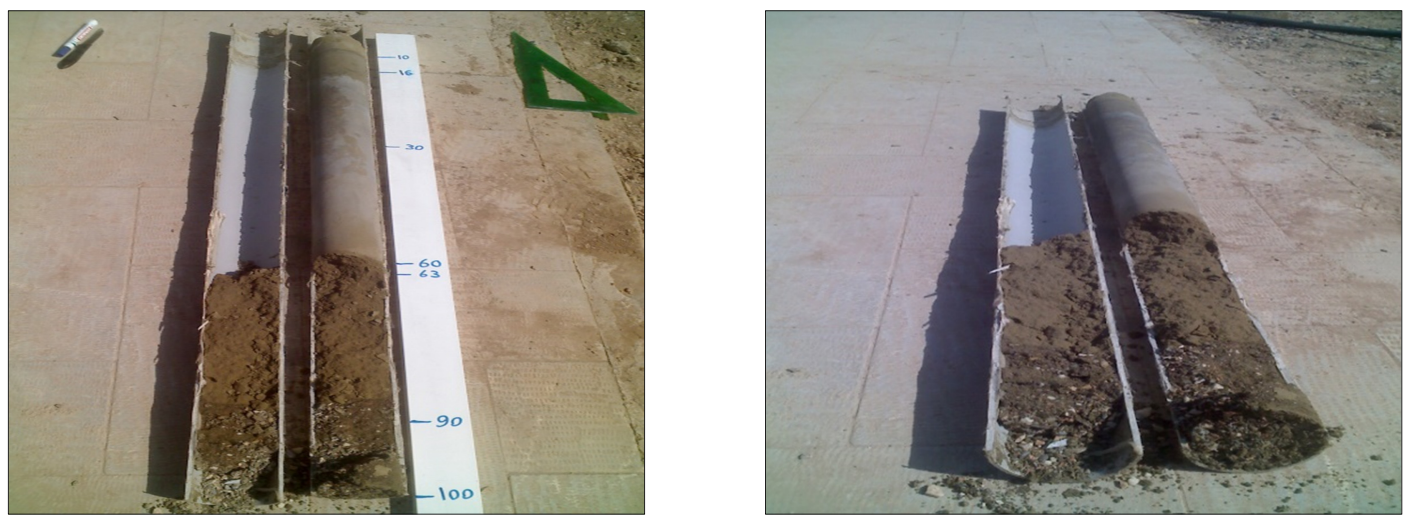

شكل م، تصوير ستون تزريقشده در دو تكرار آزمايش تثبيت بيولوزيكى

ماده پايه نخكهدارنده مانند بنتونيـت باعثث مسىشـود مـاده

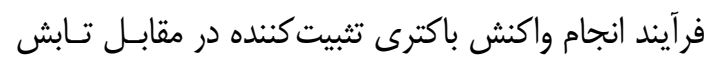

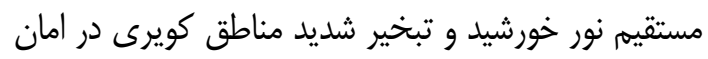

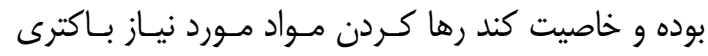

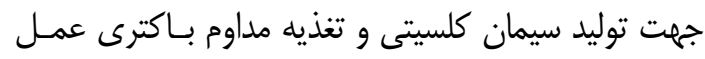

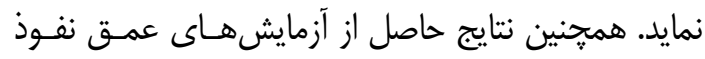

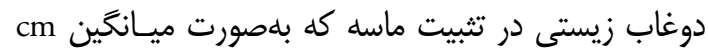

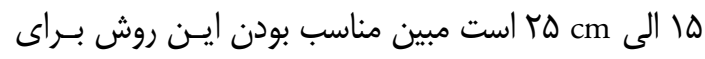

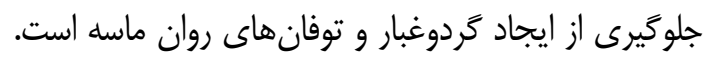

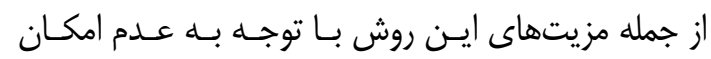

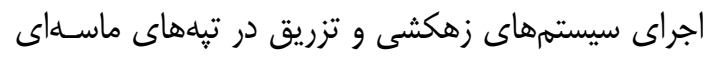

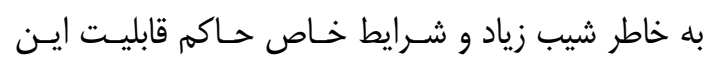

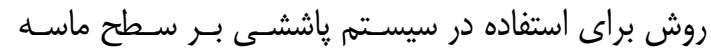

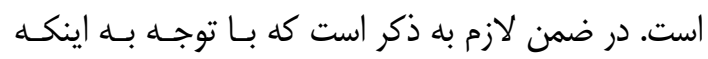

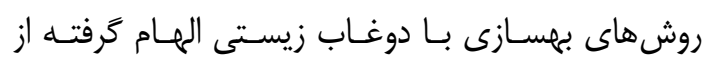

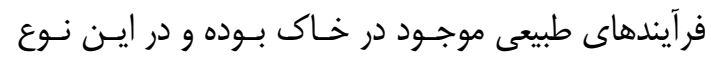

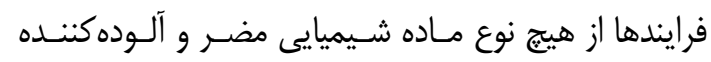

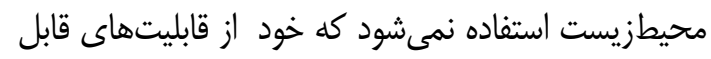
توسعه و ترويج اين روش است.

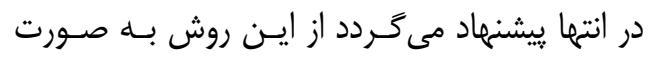

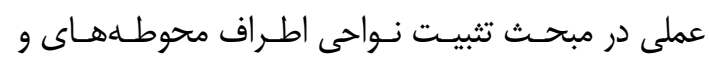
همجنين كَورهاى باستانى در بسترهاى ماسـاءى اسـتفاده كردد تا قابليتهاى آن در ميدان عمل در دراسنان رابطه با حفاظت

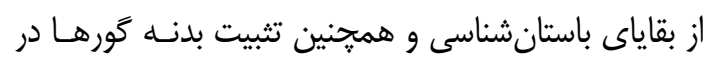
زمان كاوش و بعد از كاوش مورد ارزيابى قرار كَيرند، هـرا

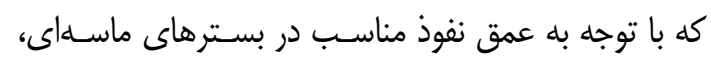

كشور محوطههاى باستانشناختى زيـادى وجـود دارد كـهـ

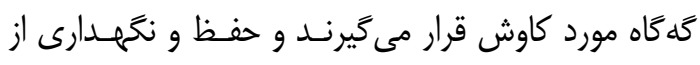

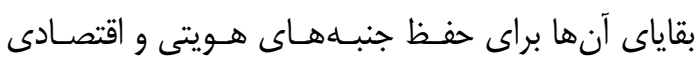

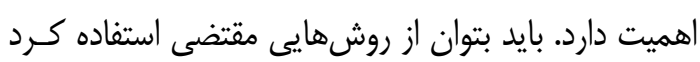

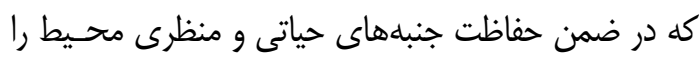

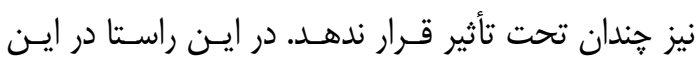

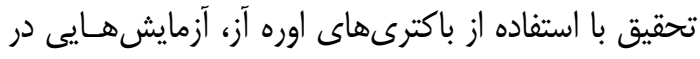

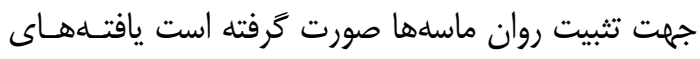

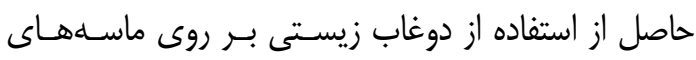

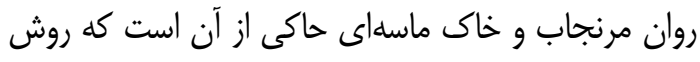

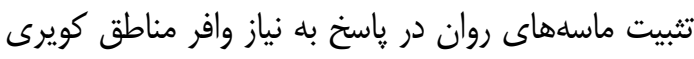
و مناطقى كه در آماج حمله توفانهاى روان ماسه هستـتند

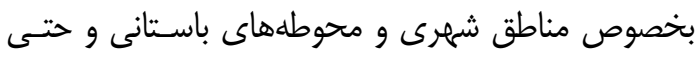

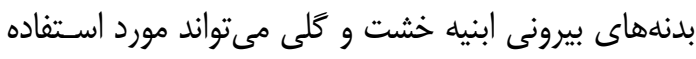

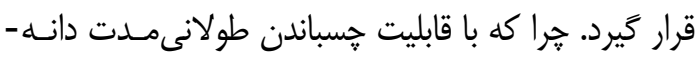

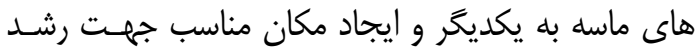

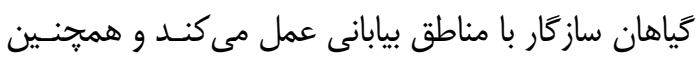

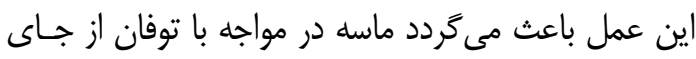
خود حركت نكند و در نتيجه از بروز بسيارى از مشـكلات

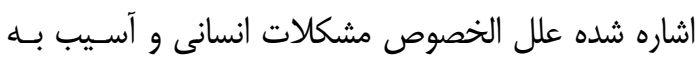
بقاياى باستانشناسى كاسته گردد.

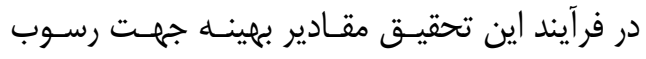

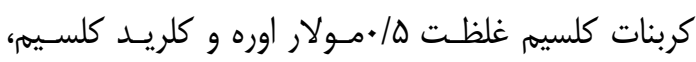

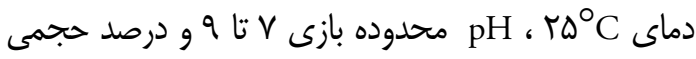

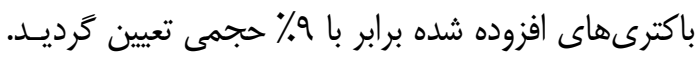

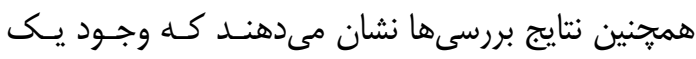




\section{منابع فارسى}

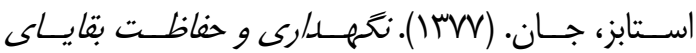

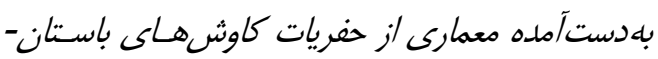

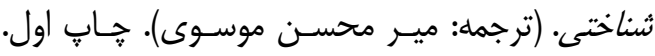

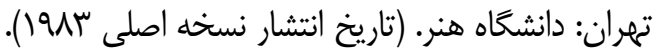

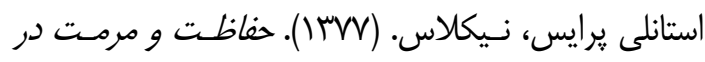

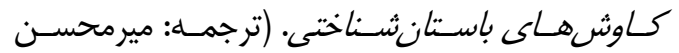

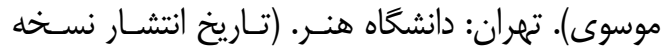
(اصلى س (194). آقايارى، عيسى. ((اqس)). بررسى تغييرات خصوصيات بايو

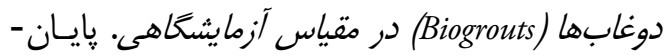

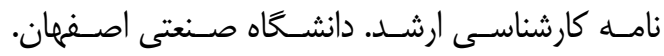

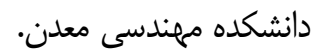

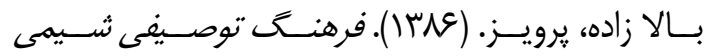

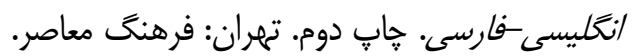

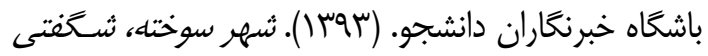

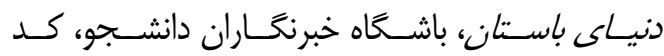

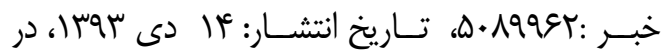

$$
\text { دسترس به آدرس: }
$$

http://cdn.yjc.ir/files/fa/news/1393/10/14/2855496 253.jpg

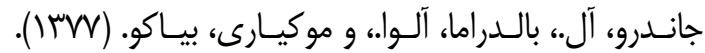

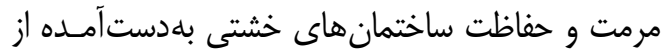

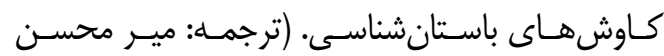
موسوى). جإ اول. تهران: دانشكاه هنر. (تاريخ انتشـار نسخه اصلى س بح1). خسروى، عباس. (INYV). تجزيه و تحليل بادهاى كاشـان

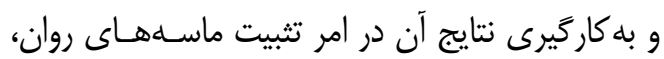
مجموعه مقالات بثزوهشى در سـيماى طبيعسى /يران

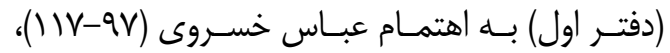
تهران: سازمان جغرافيايى نيروهاى مسلح.

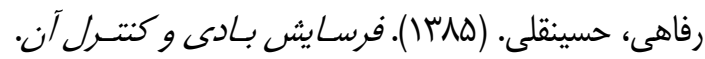
קاب جهارم. تهران: انتشارات دانشخاه تهران.

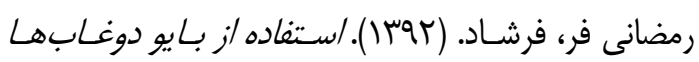
جهت تحكيم و بهسازى زمين در مقياس آزمايشكاهى

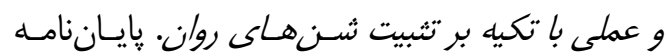

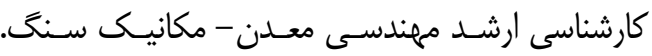
دانشكده مهندسى معدن. دانشخاه صنعتى اصفهان.

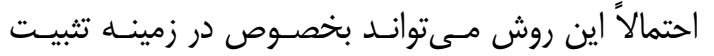

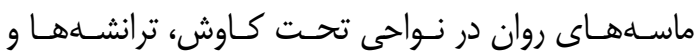

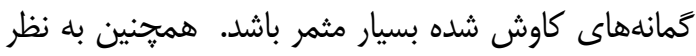

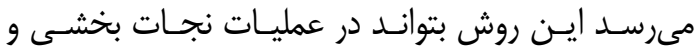
جابجايى آثار منحصربهفردى كه براى نجات آنهـا راهـى

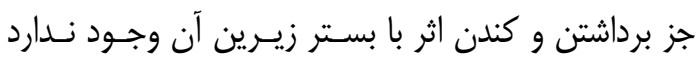

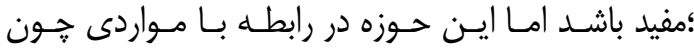

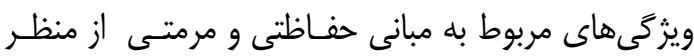

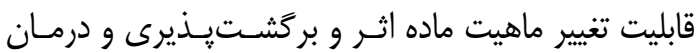
مجدد نيازمند مطالعات جدىتر و آزمون موارد فوق است.

\section{سباسگز ارى}

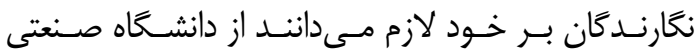

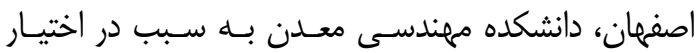

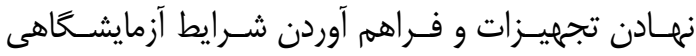

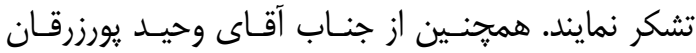
حفاظتكر و دكتر سـيد سـجادى كاوشـخر شـهر سـوخته

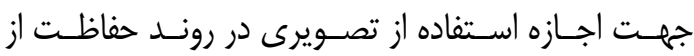

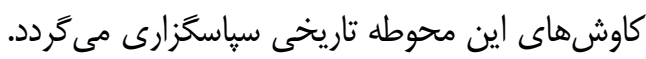

\section{بي بنوشتها}

1. بنتونيت (Bentonite)، رسى كلوييـدى داراى خاصسيت

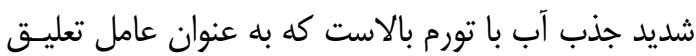

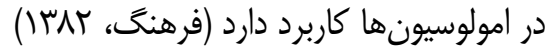

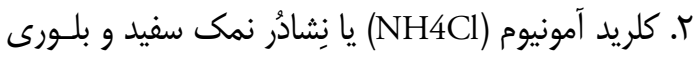

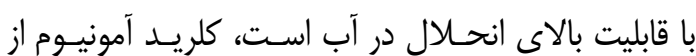

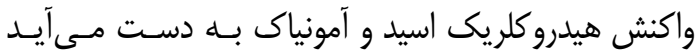

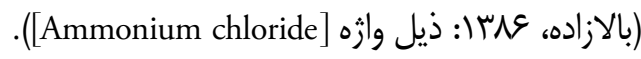

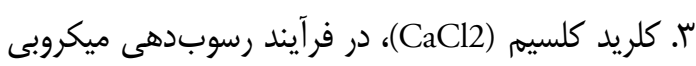
كربنات كلسيم براى تأمين يونهـاى كلسـيم مـورد نيـاز براى انجام واكنش استفاده مىشود. اين ماده در آب بسيار

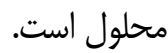

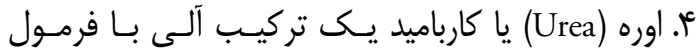
شيميايى CO(NH2)2 است كه جهت انجام اين يزوهش

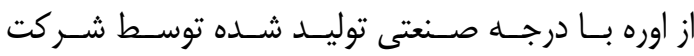

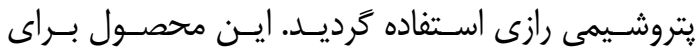
مصارف كشاورزى توليد مىشود. 


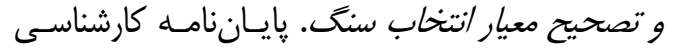

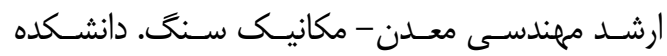

$$
\begin{aligned}
& \text { مهندسى معدن. دانشكاه صنعتى اصفهان. }
\end{aligned}
$$

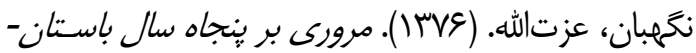

$$
\begin{aligned}
& \text { شناسى در /يران. تهران: سازمان ميراث فرهنكى. }
\end{aligned}
$$

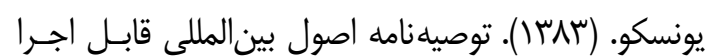

$$
\begin{aligned}
& \text { در حفارىهاى باستانشناسى، (ترجمه: فريبا مجيـدى)، }
\end{aligned}
$$

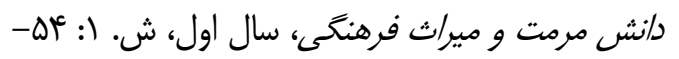

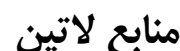

DeJong, J. T., Fritzges, M. B., \& Nüsslein, K. (2006). Microbially induced cementation to control sand response to undrained shear. Journal of Geotechnical and Geoenvironmental Engineering, 132(11), 13811392.

DeJong, J. T., Mortensen, B. M., Martinez, B. C., \& Nelson, D. C. (2010). Bio-mediated soil improvement. Ecological Engineering, 36(2), 197210.

Ferris, F. G., Stehmeier, L. G., Kantzas, A., \& Mourits, F. M. (1997). Bacteriogenic mineral plugging. Journal of Canadian Petroleum Technology, 36(09).

Gollapudi, U. K., Knutson, C. L., Bang, S. S., \& Islam, M. R. (1995). A new method for controlling leaching through permeable channels. Chemosphere, 30(4), 695-705.

Hammes, F., Seka, A., Van Hege, K., Van de Wiele, T., Vanderdeelen, J., Siciliano, S. D., \& Verstraete, W. (2003). Calcium removal from industrial wastewater by bio-catalytic $\mathrm{CaCO} 3$ precipitation. Journal of Chemical Technology and Biotechnology, 78(6), 670-677.

Ivanov, V., \& Chu, J. (2008). Applications of microorganisms to geotechnical engineering for bioclogging and biocementation of soil in situ. Reviews in Environmental Science and Bio/Technology, 7(2), 139-153.

Jonkers, H. M., Thijssen, A., Muyzer, G., Copuroglu, O., \& Schlangen, E. (2010). Application of

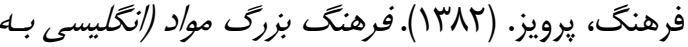

$$
\begin{aligned}
& \text { فارسى فارسى به انغليسى). جاب دوم. تهـران: سـيبيده } \\
& \text { سحر. }
\end{aligned}
$$

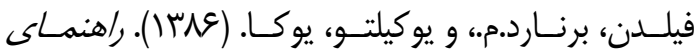

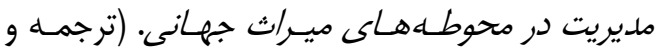

$$
\begin{aligned}
& \text { افزوده: ييروز حناجى). تهران: موسسه انتشارات و خهاب } \\
& \text { دانشكاه تهران. (تاريخ انتشار نسخه اصلى (1991). }
\end{aligned}
$$

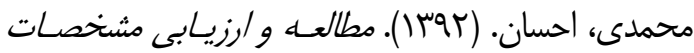

$$
\begin{aligned}
& \text { سنك هاى بهسازى شلده جهت /ستفاده در موجشكنها }
\end{aligned}
$$

bacteria as self-healing agent for the development of sustainable concrete. Ecological engineering, 36(2), 230-235.

Le Metayer-Levrel, G., Castanier, S., Orial, G., Loubiere, J. F., \& Perthuisot, J. P. (1999). Applications of bacterial carbonatogenesis to the protection and regeneration of limestones in buildings and historic patrimony. Sedimentary geology, 126(1), 25-34.

Mitchell, A. C., \& Ferris, F. G. (2005). The coprecipitation of $\mathrm{Sr}$ into calcite precipitates induced by bacterial ureolysis in artificial groundwater: temperature and kinetic dependence. Geochimica et Cosmochimica Acta, 69(17), 4199-4210.

Ozdogan, A. (2010). A study on the triaxial shear behavior and microstructure of biologically treated sand specimens (Doctoral dissertation, University of Delaware).

Ramachandran, S. K., Ramakrishnan, V., \& Bang, S. S. (2001). Remediation of concrete using microorganisms ACI Materials journal, 98(1), 3-9.

Reuben, R. (2003). Chemical grouting and soil stabilization. Rutgers University, Marcel Dekker Inc., New Jersey, 558.

Van Paassen, L. A., van Loosdrecht, M. C. M., Pieron, M., Mulder, A., Ngan-Tillard, D. J. M., \& Van der Linden, T. J. M. (2009, January). Strength and deformation of biologically cemented sandstone. In ISRM Regional Symposium-EUROCK 2009. International Society for Rock Mechanics. 
